Web Jurnal:

http://ejournal.kemenperin.go.id/jli

\title{
Aplikasi teknik biosorpsi menggunakan biosorben kulit batang sagu, arang aktif kulit buah kakao dan cangkang langkitang untuk mengolah air limbah CPO
}

\section{Application of biosorption technique using biosorbent sago bark, activated carbon from cacao shells, and Faunus ater shells to treat CPO wastewater}

\author{
Rahmiana Zein*1, Imran Nazar ${ }^{2}$, Zilfa $^{3}$ \\ 1 Laboratorium Kimia Analisis Lingkungan, Jurusan Kimia FMIPA Universitas Andalas \\ Limau Manis, Pauh, Kota Padang, Sumatera Barat, Indonesia. \\ 2 Program Pascasarjana, Jurusan Kimia FMIPA Universitas Andalas \\ Limau Manis, Pauh, Kota Padang, Sumatera Barat, Indonesia. \\ 3 Laboratorium Kimia Analisis Terapan, Jurusan Kimia FMIPA Universitas Andalas \\ Limau Manis, Pauh, Kota Padang, Sumatera Barat, Indonesia. \\ * e-mail: rzein@sci.unand.ac.id
}

\begin{tabular}{l}
\hline INFO ARTIKEL \\
\hline Sejarah artikel: \\
Diterima: \\
20 Februari 2020 \\
Direvisi: \\
4 Juni 2020 \\
Diterbitkan: \\
29 Juni 2020
\end{tabular}

\section{Kata kunci:}

air Limbah CPO;

adsorpsi;

kulit batang sagu;

kulit buah kakao;

cangkang langkitang

\begin{abstract}
ABSTRAK
Penelitian ini dilakukan untuk mengetahui kemampuan biosorben kulit batang sagu, arang aktif kulit buah kakao dan cangkang langkitang dalam mengolah air limbah CPO. Penelitian dilakukan pada massa dan laju alir terbaik untuk pengolahan air limbah CPO dengan sistem aliran kontinu dan sistem aliran siklus serta menentukan kapasitas biosorpsi biosorben. Pengujian air limbah dan air olahan adalah $\mathrm{pH}$, TSS, BOD dan COD. Analisis biosorben dilakukan untuk melihat gugus fungsi dengan FTIR, morfologi permukaan dengan SEM dan komposisi kimia biosorben dengan XRF. Massa dan laju alir terbaik masing-masing biosorben yang didapatkan dari percobaan yaitu 100 gram dan $100 \mathrm{~mL} /$ menit. Penelitian dengan sistem kontinu didapatkan hasil air olahan dengan nilai pH 6 s.d 7 dan persentase penurunan nilai TSS 99,53\%; BOD 57,23\% dan COD 90,85\%. Penelitian dengan sistem kontinu dan siklus sebanyak 3 siklus didapatkan hasil air olahan dengan pH 6 s.d 7 dan persentase penurunan nilai TSS 99,66\%; BOD 81,69\% dan COD 95,90\%. Hasil penelitian uji kinerja sistem, biosorben mampu mengolah air limbah sebanyak 12,5 L. Analisis biosorben menggunakan SEM, FTIR dan XRF didapatkan hasil yang berbeda antara biosorben sebelum dan sesudah kontak dengan air limbah yang menunjukan biosorben dan air limbah terjadi interaksi (biosorpsi).
\end{abstract}

Keywords:

CPO Wastewater;

adsorption;

sago bark;

cacao shells;

faunus ater shell

\begin{abstract}
This research was treated to determine the ability of sago bark biosorbents, activated carbon from cacao shells, and faunus ater shells in treating CPO wastewater. This research treated at the best mass and flow rate for CPO wastewater treatment with a continuous flow system and a cycle flow system and determines the biosorption capacity of biosorbents. Testing of the wastewater and treated water were carried out on $\mathrm{pH}$, TSS, BOD, and COD. Biosorbent analysis was treated out to see functional groups with FTIR, surface morphology with SEM, and chemical composition of biosorbents with $X R F$. The best mass and flow rate of each biosorbent was 100 grams and $100 \mathrm{~mL} / \mathrm{min}$. Research with a continuous system received the results of processed water with a pH value of 6 to 7 and a percentage decrease in TSS value of 99.53\%, BOD 57.23\% and COD $90.85 \%$. Research with continuous systems and cycles of 3 cycles obtained results of treated water with a pH of 6 to 7 and the percentage decrease in TSS value of $99.66 \%$, BOD $81.69 \%$ and COD 95.90\%. The system performance test result showed that biosorbents were able to treat 12.5 L. Biosorbent analysis using SEM, FTIR, and XRF showed different results between biosorbents before and after contact with wastewater, which showed biosorbents and wastewater interactions (biosorption).
\end{abstract}




\section{Pendahuluan}

Crude palm oil (CPO) merupakan produk minyak nabati yang diekstrak dari kelapa sawit. Minyak CPO berfungsi sebagai bahan baku untuk produksi minyak sayur, vitamin E secara komersil, phitosterol, squelene, dan karoten. Minyak CPO juga merupakan bahan baku produk nabati dan bahan baku untuk produksi bahan bakar biodiesel. (Rodrigues et al., 2014; Cheah et al., 2018).

Industri pengolahan kelapa sawit, mengolah kelapa sawit menjadi produk setengah jadi seperti CPO atau produk jadi seperti minyak kelapa sawit, kosmetik dan sebagainya. Masalah dari Industri kelapa sawit adalah hasil samping yang dihasilkan berupa limbah padat, cair dan gas. Agar tidak mencemari lingkungan, air limbah yang dihasilkan dari pabrik pengolahan CPO terlebih dahulu harus diolah sebelum dialirkan ke perairan lepas. (Wong et al., 2013; Zahrim et al., 2017; Mohd-Nor et al., 2018).

Ciri fisik air limbah pabrik CPO yaitu kental, berwarna coklat kehitaman, berminyak dan berbau. Air limbah CPO biasanya mengandung minyak dan lemak dengan konsentrasi $0,6-0,7 \%$, TSS 4-5\%, pH 4-5, pada suhu $80-90{ }^{\circ} \mathrm{C}$ rata-rata memiliki nilai COD 50.000 $\mathrm{mg} / \mathrm{L}$ dan BOD $25.000 \mathrm{mg} / \mathrm{L}$ dan mengandung senyawa fenolik yang sangat tinggi. (Wong et al., 2013; Theerachat, Tanapong and Chulalaksananukul, 2017; Zahrim et al., 2017). Minyak dan lemak dapat membentuk lapisan film di permukaan air yang dapat menghalangi masuknya oksigen masuk ke dalam air sehingga menyebabkan menurunnya kadar oksigen terlarut dalam air, serta menyebabkan beberapa masalah operasional seperti penyumbatan sistem saluran pembuangan, bau yang tidak sedap dan busa yang tidak nyaman dipandang. Kandungan minyak dan lemak yang tinggi dapat menyebabkan hewan dalam air sulit hidup. Air limbah CPO yang berwarna coklat kehitaman, jika dibuang langsung ke perairan lepas dapat menimbulkan masalah estetika dan mempengaruhi aktivitas fotosintesis dengan mengurangi penetrasi sinar matahari yang masuk kedalam air. Nilai COD dan BOD yang tinggi dapat menggannggu kehidupan hewan di dalam air dan tidak bisa dikonsumsi. Keberadaan senyawa fenolik menyebabkan beberapa efek biologis seperti fototoksik dan efek antimikroba. (Wong et al., 2013; Theerachat, Tanapong and Chulalaksananukul, 2017; Zahrim et al., 2017). Bau yang tidak sedap disebabkan oleh gas yang dihasilkan senyawa organik yang terurai akibat adanya panas, cahaya matahari dan bakteri yang menguap keudara. Bau ini dapat mengganggu pernafasan manusia. Gas hasil penguraian air limbah CPO biasanya berupa $\mathrm{CO}_{2}$ dan gas metan. (Wong et al., 2013; Zahrim et al., 2017; Cheah et al., 2018).

Berbagai metode / teknologi dikembangkan dalam mengatasi permasalahan limbah pabrik kelapa sawit baik padat, cair ataupun gas. Metode pengolahan air limbah CPO diantaranya adalah pengolahan secara fisik (penyaringan dan pengendapan), pengolahan secara kimia yaitu penambahan sejenis bahan kimia kedalam air limbah seperti koagulan dan flokulan dan pengolahan secara biologis dengan menggunakan mikro organisme dan biosorben yang berasal dari tumbuhan dan hewan.
(Wong et al., 2013; Zein, Swesti, et al., 2016; Theerachat, Tanapong and Chulalaksananukul, 2017; Zahrim et al., 2017; Cheah et al., 2018).

Metode yang umum digunakan adalah metode filtrasi atau penyaringan. Metode penyaringan yang sedang dikembangkan adalah metode multi soil layering (MSL) atau lapisan multi media (LMM). MSL selain menggunakan metode penyaringan dan proses adsorbsi karena adanya penambahan biosorben seperti arang aktif juga terjadi proses ion exchange karena adanya pertlite atau zeolite yang mengandung oksida logam dan proses penguraian oleh mikroorganisme yang bersumber dari tanah yang digunakan. (Zein, Ningsih, et al., 2016; Zein, Swesti, et al., 2016). Metode lain yang sedang dikembangkan adalah metode biosorpsi. Biosorpsi adalah proses penghilangan polutan oleh berbagai biomassa seperti alga, bakteri dan limbah pertanian (Tabaraki and Heidarizadi, 2018). Biosorpsi merupakan teknik penyerapan (adsorpsi) yang menggunakan adsorben yang berasal dari makhluk hidup (tumbuhan dan hewan) yang disebut dengan biosorben. Biosorben dari tumbuhan contohnya adalah kulit batang sagu dan sekam padi (Safa and Bhatti, 2011; Fauzia et al., 2018), sedangkan biosorben dari hewan contohnya adalah cangkang langkitang (Pratiwi, Zein and Aziz, 2016; Barus, Zein and Syukri, 2017). Biosorben yang sudah diteliti diantaranya biosorben kulit salak (Zein et al., 2018), arang aktif dari kulit kakao (Yetri et al., 2017), kulit sagu (Fauzia et al., 2018), kerang dan cangkang langkitang (Barus, Zein and Syukri, 2017) serta sekam padi dan abunya (Safa and Bhatti, 2011; Iqbal et al., 2018).

Berbagai penelitian telah dilakukan untuk mengolah air limbah dengan menerapkan teknik biosorpsi. Teknik ini mempunyai beberapa kelebihan dibanding dengan teknik lain, diantaranya biaya rendah, mudah di regenerasi dan tidak ada generasi lumpur. Dalam biosorpsi kelompok fungsional yang terkandung di dinding sel biomassa (seperti $\mathrm{OH}, \mathrm{COOH}$ dan $\mathrm{NH}_{2}$ ) berinteraksi dengan polutan dan mengikat polutan (Tabaraki and Heidarizadi, 2018). Beberapa penelitian yang telah dilakukan diantaranya biosorpsi menggunakan kulit sagu yang dilakukan Syifa Fauzia dkk, dimana Fauzia dkk menyimpulkan kulit batang sagu dapat digunakan sebagai adsorben untuk $\mathrm{Pb}$ (II) dimana Adsorpsi $\mathrm{Pb}$ (II) dengan Sagu Bark (Metroxylon Sagu) mencapai puncak pada $\mathrm{pH} 5$, waktu kontak 60 menit, konsentrasi awal $600 \mathrm{mg} / \mathrm{L}$, kecepatan pengadukan $100 \mathrm{rpm}$, dosis adsorben $0,1 \mathrm{~g}$ dan kapasitas adsorpsi 31,4375 mg/g (Fauzia et al., 2018). Penelitian lainnya oleh Niko Dwinanta Barus dkk dan Yuli Yetri dkk. Barus dkk menyatakan, kerang dan cangkang langkitang dapat digunakan sebagai biosorben untuk penjernihan air sumur dengan efisiensi penjernihan air sumur dengan menggunakan kerang berkisar antara $54,8 \%$ s.d 99,6\% dan dengan menggunakan cangkang langkitang berkisar antara 77,7\% s.d 99,4\% (Barus, Zein and Syukri, 2017). Yetri menyatakan biosorben arang aktif kulit kakao dapat digunakan untuk menyerap zat warna Tartrazin dengan daya serapan mencapai 99,08\% (Yetri et al., 2017).

Teknik biososrpsi yang telah diterapkan pada beberapa penelitian memiliki biaya operasional rendah, 
mudah digunakan dan memiliki daya biosorpsi tinggi mencapai hampir $100 \%$. Biaya rendah karena menggunakan bahan limbah pertanian dan hewan seperti kulit batang sagu, cangkang langkitang dan kulit buah kakao yang sangat mudah didapatkan karena keberadaannya sangat melimpah dan tidak memerlukan biaya untuk memperolehnya. Mudah digunakan karena prosesnya yang sederhana, dimana hanya perlu proses pemanasan pada alat bersuhu tinggi atau pembakaran, penghalusan serta aktivasi untuk arang aktif kulit kakao dan sekam padi, sedangkan untuk bahan lain seperti kulit batang sagu dan cangkang langkitang hanya menggunakan proses penumbukan atau penghalusan dan aktivasi. Kelemahan dari teknik biososrpsi pada penelitian yang telah dilakukan adalah waktu kontak yang lama dan kecepatan alir yang rendah. (Barus, Zein and Syukri, 2017; Yetri et al., 2017; Fauzia et al., 2018).

Berdasarkan latar belakang tersebut, dilakukan penelitian tentang pengolahan air limbah CPO. Air limbah CPO yang digunakan adalah air limbah pengolahan CPO yaitu air limbah yang dihasilkan dari pengolahan CPO. Untuk mendapatkan hasil yang optimal dalam mengolah air limbah CPO digunakan tiga jenis biosorben yaitu kulit batang sagu, arang aktif kulit buah kakao dan cangkang langkitang dan ukuran meterial biosorben diperbesar guna memperkecil waktu kontak dan memperbesar laju alirnya. Pemilihan ketiga biosorben tersebut dikarenakan keberadaanya sangat melimpah dan sangat mudah didapatkan serta tidak perlu mengeluarkan biaya untuk memperolehnya. Teknik biosorpsi dilakukan adalah sistem kontinu dengan menggunakan kolom akrilik, ember plastik sebagai bak penampung, dan keran untuk mengatur laju alir air keluar air limbah.

Tujuan penelitian ini adalah mendesain penelitian dengan memanfaatkan biosorben kulit batang sagu, arang aktif kulit buah kakao dan cangkang langkitang untuk mengolah air limbah pengolahan CPO. Indikator penelitian ini adalah pengukuran nilai $\mathrm{pH}$, TSS, BOD dan COD. Pada penelitian diharapkan terjadinya perbaikan kualitas air limbah berdasarkan indikator tersebut.

\section{Metode}

Peralatan yang digunakan untuk mengolah air limbah CPO adalah kolom dari bahan akrilik dengan ukuran $(5 \mathrm{x}$ $5 \times 50) \mathrm{cm}$ yang dihubungkan dengan bak penampung ember plastik. pH meter merk Hanna untuk mengukur pH. Pompa vacum, corong, kertas saring whatman 42 milipore, oven (suhu 103-105 ${ }^{\circ} \mathrm{C}$ ) dan desikator untuk mengukur TSS. Botol winkler, inkubator BOD merk Hanna, tabung nesler, penangas refluks, termometer, erlenmeyer dan buret untuk penentuan BOD dan COD. SEM-EDX merk Ion Sputter, FTIR merk Parkinelmer Frontier) dan XRF merk Panalytical Epsilon 3 untuk analisis morfologi permukaan, gugus fungsi dan komposisi kimia biosorben. Peralatan lainnya adalah neraca analitik, botol sampel, dirigent, gelas piala, labu ukur, kaca arloji, pipet volume, bola hisap, batang pengaduk, penjepit dan pipet tetes.

Bahan yang digunakan antara lain biosorben (kulit sagu, arang aktif kulit kakao dan cangkang langkitang dengan ukuran 300-300 $\mu \mathrm{m}$ ), air limbah CPO (hasil pengolahan $\mathrm{CPO})$, aquadest, asam sulfat $\left(\mathrm{H}_{2} \mathrm{SO}_{4}\right)$ p.a, natrium oksalat $\left(\mathrm{Na}_{2} \mathrm{C}_{2} \mathrm{O}_{4}\right)$, ferro ammonium sulfat (FAS) $\left\{\mathrm{Fe}\left(\mathrm{NH}_{4}\right)_{2}(\mathrm{SO} 4)_{2} \cdot 6 \mathrm{H}_{2} \mathrm{O}\right\}$, indikator ferroin, kalium dikromat $\left(\mathrm{K}_{2} \mathrm{Cr}_{2} \mathrm{O}_{7}\right)$, natrium sulfat $\left(\mathrm{Na}_{2} \mathrm{SO}_{4}\right)$ anhidrat p.a, air suling bebas nitrat (Aquabides), alkali azida, (natrium tiosulfat) $\mathrm{Na}_{2} \mathrm{~S}_{2} \mathrm{O}_{3} .2 \mathrm{H}_{2} \mathrm{O}$, Amilum, $\mathrm{Na}_{2} \mathrm{SO}_{4}$ dan $\mathrm{HCl}$. Semua bahan yang dipakai adalah produksi merk.

Langkah pertama adalah penyiapan biosorben dan merakit peralatan yang terdiri dari bak penampung, kolom dan penampung efluen. Bak penampung dan kolom dihubungkan menggunakan pipa PVC dengan menggunakan katup dan pada kolom dipasang keran tempat air keluar. Sebelum biosorben dimasukan ke dalam kolom terlebih dahulu dimasukan kapas sebagai penyangga biosorben.

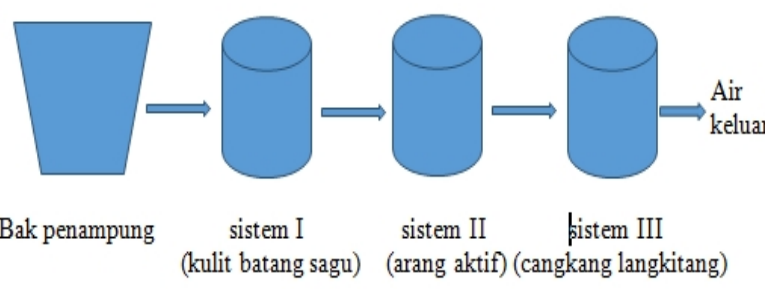

Gambar 1. Skema alat pengolahan air limbah CPO dengan sistem kontinu

Setelah perakitan alat, dilakukan pengujian pengaruh massa biosorben dan laju alir air keluar pada sistem guna mendapatkan massa biosorben dan laju alir terbaik. Biosorben yang digunakan adalah kulit batang sagu, arang aktif kulit buah kakao dan cangkang langkitang. Penentuan pengaruh massa biosorben dan laju alir air keluar dilakukan untuk masing-masing jenis biosorben yang digunakan. Pengaruh massa biosorben ditentukan berdasarkan percobaan variasi massa biosorben $25 \mathrm{~g}, 50$ g, $75 \mathrm{~g}$ dan $100 \mathrm{~g}$ dengan laju alir $200 \mathrm{~mL} / \mathrm{menit}$. dan pengaruh laju alir ditentukan berdasarkan percobaan variasi laju alir pada massa terbaik. Variasi laju alir air keluar yang digunakan $100 \mathrm{~mL} / \mathrm{menit}, 200 \mathrm{~mL} / \mathrm{menit}$ dan $300 \mathrm{~mL} / \mathrm{menit}$. Massa dan laju alir air keluar terbaik ditetapkan berdasarkan kualitas $\mathrm{pH}$, TSS, BOD dan COD air yang dihasilkan. Berikutnya dilakukan pengolhan air limbah secara kontinu menggunakan tiga biosorben yang dialirkan secara bertahap. Air yang dihasilkan diuji pH, TSS, BOD dan COD untuk mengetahui kualitasnya. Kemudian dilakukan percobaan sistem kontinu dan siklus sebanyak tiga kali. Pada sistem kontinu air limbah dialirkan melewati biosorben kulit sagu, kemudian arang aktif kulit kakao dan terakhir cangkang langkitang. Pada sistem siklus selain dialirkan melalui tiga jenis biosorben, air hasil olahan diolah kembali dengan mengalirkannya melalui 3 jenis biosorben yang sama dan proses tersebut dilakukan sebanyak tiga kali (tiga siklus). Air yang dihasilkan diuji $\mathrm{pH}$, TSS, BOD dan COD untuk mengetahui kualitasnya. Penentuan kapasitas biosorpsi biosorben dilakukan dengan cara mengalirkan air limbah secara terus menerus kedalam kolom berisi biosorben pada kondisi massa dan laju alir terbaik. Air yang dialirkan sebanyak $15 \mathrm{~L}$. 
Sampel air diambil setiap 2,5 L untuk menguji kualitas airnya.

Kinerja biosorben diperoleh dengan melakukan analisis menggunakan SEM, FTIR dan XRF untuk ketiga biosorben baik sebelum maupun sesudah kontak dengan air limbah. SEM digunakan untuk melihat perbedaan morfologi permukaan biosorben, FTIR digunakan untuk melihat perbedaan gugus fungsi biosorben dan XRF untuk melihat perbedaan komposisi kimia biosorben .

\section{Hasil dan pembahasan}

\subsection{Pengaruh massa biosorben pada pengolahan air limbah CPO}

Penelitian yang telah dilakukan baik dengan menggunakan biosorben kulit batang sagu, arang aktif, cangkang langkitang maupun biosorben lainnya, pada umumnya menggunakan ukuran partikel antara 100$300 \mu \mathrm{m}$ dengan massa biosorben yang digunakan 1-5 gram untuk mendapatkan kualitas air bersih namun dengan laju alir 5 s.d $25 \mathrm{~mL} / \mathrm{menit}$ (Barus, Zein and Syukri, 2017; Yetri et al., 2017; Fauzia et al., 2018). Berbeda dengan penelitian sebelumnya, disini dilakukan penelitian dengan ukuran pertikel yang lebih besar dengan tujuan untuk mendapatkan laju alir yang besar pula. Untuk medapakan kualitas air yang bagus dengan ukuran partikel yang lebih besar dan laju alir yang lebih besar sehingga diperlukan massa biosorben yang lebih banyak. Penggunaan ukuran partikel besar akan memperbesar jarak antar partikel (tidak rapat) yang menyebabkan laju alir besar karena penghalangnya kecil. Selain itu dengan ukuran partikel besar berarti memperkecil luas permukaan biosorben untuk kontak dengan air limbah. Laju alir yang besar ini menunjukan kecilnya waktu kontak air limbah dengan biosorben. Luas permukaan yang kecil dan waktu kontak yang kecil yang menyebabkan penggunaan biosorben lebih banyak dari pada dengan ukuran halus (Istighfarini, Daud and Edward, 2017).

Penelitian dilakukan dengan variasi massa biosorben 25 gram, 50 gram, 75 gram dan 100 gram untuk tiap-tiap biosorben. Variasi massa tersebut didasarkan pada ketersediaan material biosorben yang disiapkan dengan tujuan untuk menentukan massa terbaik dari keempat variasi massa biosorben tersebut. Penentuan massa terbaik dengan variasi massa tersebut dilakukan pada laju alir yang konstan yakni $200 \mathrm{~mL} /$ menit, dan dari penelitian tersebut didapatkan hasil yang dapat dilihat pada Gambar 2.
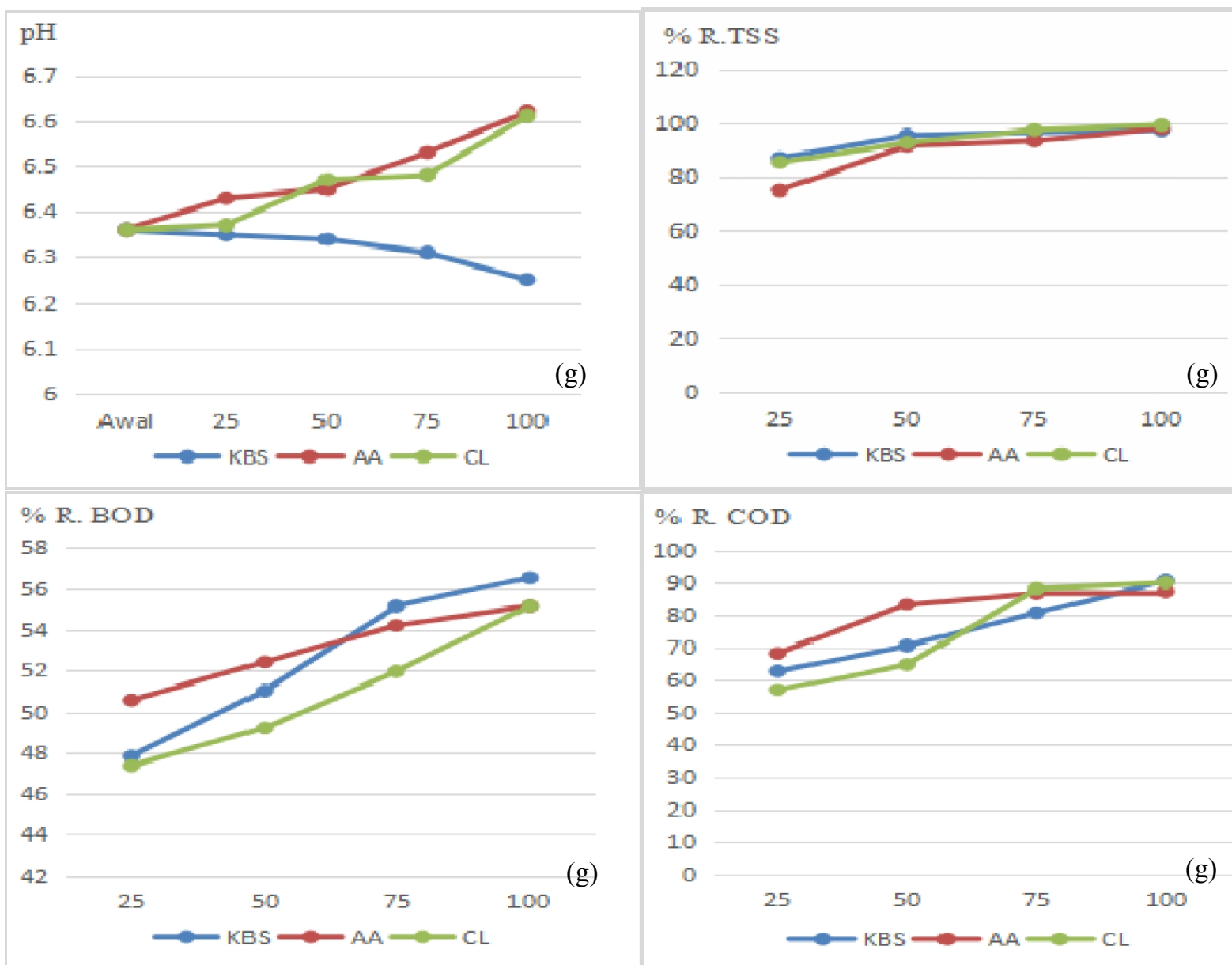

Gambar 2. Effek massa biosorben terhadap pH, penurunan nilai TSS, BOD dan COD air limbah pengolahan CPO.

Ket $\quad \begin{aligned} \% \text { R. TSS } & =\text { persentase removal TSS } \\ \% \text { R. BOD } & =\text { persentase removal BOD } \\ \% \text { R. COD } & =\text { persentase removal COD }\end{aligned}$

KBS = kulit batang sagu

AA $=$ arang aktif kulit kakao

$\mathrm{CL} \quad$ cangkang langkitang 
Hasil penelitian menunjukan semakin banyak massa biosorben yang digunakan untuk pengolahan air limbah semakin bagus kualitas air yang dihasilkan dari pengukuran $\mathrm{pH}$, TSS, BOD dan COD. Pada hasil terlihat massa optimum berada pada massa 100 gram, dimana $\mathrm{pH}$ berada antara 6 dan 7, persentase penurunan nilai TSS, BOD dan COD memiliki nilai persentase tertinggi dibandingkan dengan massa-massa yang lain. Perubahan $\mathrm{pH}$ terjadi akibat interaksi air limbah denga ion $\mathrm{H}^{+}$dari biosorben. Interaksi tersebut berupa penyerapan ion $\mathrm{H}^{+}$ dari air limbah oleh biososrben dan lepasnya ion $\mathrm{OH}^{-}$ kedalam air limbah. Meskipun nilai TSS untuk biosorben kulit batang sagu dan arang aktif kulit buah kakao sudah kecil namun belum memenuhi standar air limbah yaitu $250 \mathrm{mg} / \mathrm{L}$ sesuai dengan peraturan menteri lingkungan hidup tahun 2014 (Mentri Lingkungan Hidup, 2014).

\subsection{Pengaruh laju alir air limbah pada sistem}

Merujuk pada Massa terbaik dari variasi massa biosorben yang sudah dicobakan, kemudian langkah berikutnya pada kondisi tersebut ditentukan laju alir terbaik dengn variasi laju alir yakni $100 \mathrm{~mL} /$ menit, 200 $\mathrm{mL} / \mathrm{menit}$ dan $300 \mathrm{~mL} / \mathrm{menit}$. Penelitian yang dilakukan diperoleh hasil sebagai berikut seperti terlihat pada Gambar 3.



Gambar 3. Effek laju alir air keluar terhadap pH, penurunan nilai TSS,BOD dan COD air limbah pengolahan CPO.

Data penelitian diperoleh laju alir paling baik berada pada laju alir $100 \mathrm{~mL} / \mathrm{menit}$ dimana pada laju alir tersebut dihasilkan kualitas air yang lebih bagus daripada laju alir yang lebih besar dari percobaan. Laju alir ini jauh lebih besar daripada penelitian sebelumnya yang hanya memiliki laju alir $5 \mathrm{s.d} 25 \mathrm{ml} /$ menit (Barus, Zein and Syukri, 2017; Yetri et al., 2017; Fauzia et al., 2018).

Semakin kecil laju alir air limbah yang dialirkan, semakin kecil pula tekanan yang diberikan oleh air limbah tersebut. Semakin kecil tekanan dari air limbah yang dialirkan, semakin kecil pula laju alir air keluar yang dihasilkan dan semakin kecil pula material yang terbawa oleh aliran air limbah yang menyebabkan semakin kecil pula nilai TSS, BOD dan COD air limbah. Semakin kecil nilai TSS, BOD dan COD air limbah berarti \% penurunannya makin besar (Dharma and Prasetyo, 2012; Sy et al., 2017).

\subsection{Pengaruh aliran kontinu pada sistem.}

Sistem kontinu merupakan sistem pengolahan air limbah yang dituju oleh peneliti, dimana dengan sistem ini diharapkan kualitas air limbah yang didapatkan memiliki nilai lebih bagus dan memenuhi standar baku mutu air limbah CPO yang diperbolehkan dialirkan keperairan atau sungai. Pengolahan sistem kontinu ini, air limbah pertama kali masuk pada fkolom berisi biosorben kulit batang sagu dan hasil saringannya dialirkan menuju kolom berisi arang aktif kulit buah 
kakao dan seterusnya hasilnya dialirkan menuju kolom berisi cangkang langkitang.

Susunan kolom ini didasarkan pada artikel dimana kulit batang sagu optimal dalam menyerap minyak (Wahi et al., 2014), arang aktif optimal untuk menyerap warna dan bau (Purnamawati and Utami, 2014; Yani, Nurcahyani and Rahayuningsih, 2014) sedangkan cangkang langkitang optimal dalam menaikan $\mathrm{pH}$ (Barus, Zein and Syukri, 2017). Penghilangan kandungan minyak ditujukan supaya kinerja biosorben berikutnya lebih optimal dan penempatan cangkang langkitang pada kolom ktiga karena diharapkan $\mathrm{pH}$ air didapatkan netral atau naik. Hasil penelitian pengolahan air limbah sistem kontinu dapat dilihat pada Gambar 4.
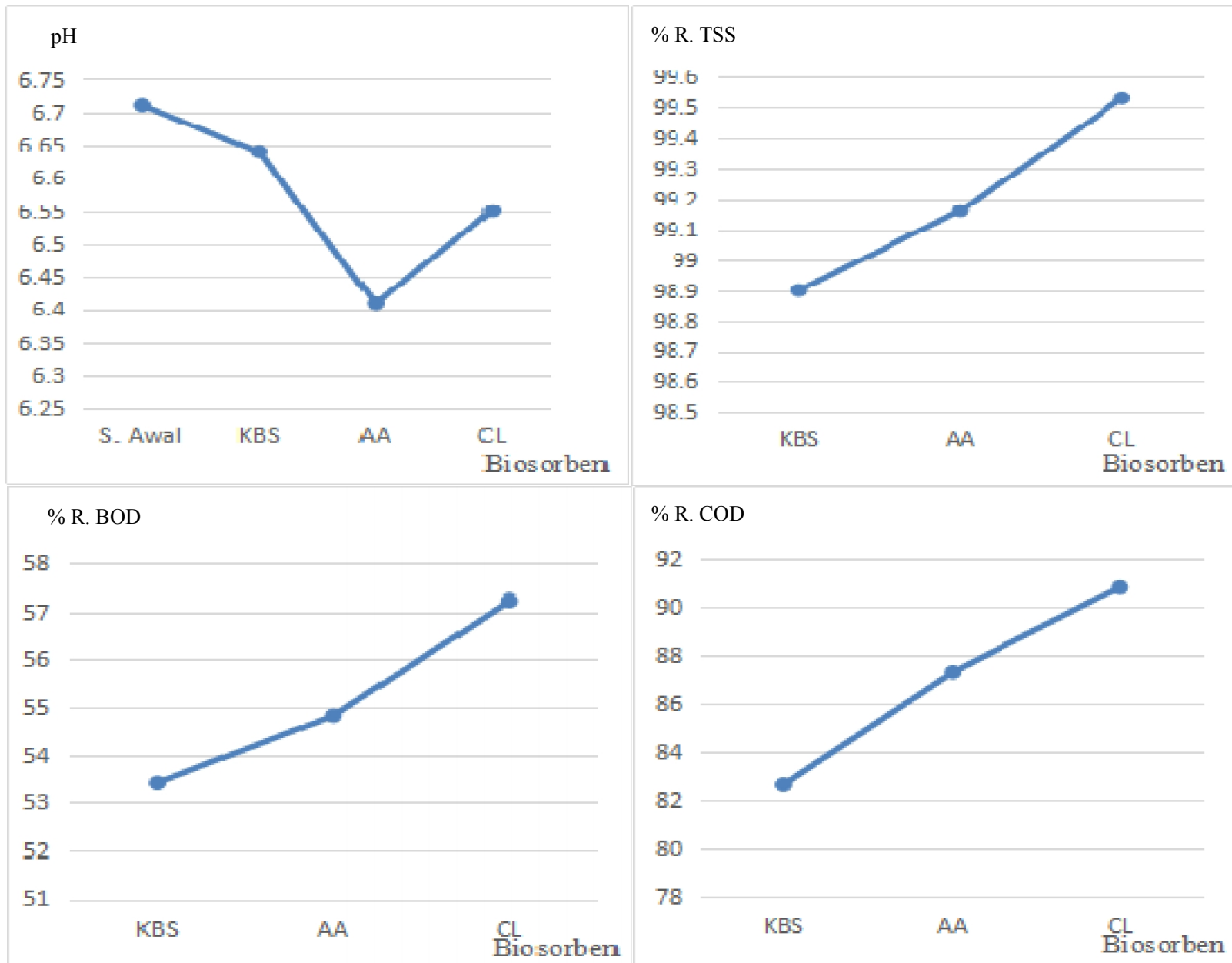

Gambar 4. Effek sistem kontinu terhadap pH, penurunan nilai TSS, BOD dan COD air limbah pengolahan CPO.

Gambar 4 memperlihatkan kualitas air yang dihasilkan jauh lebih bagus menggunakan sistem kontinu dengan menggunakan tiga jenis biosorben dimana air limbah pengolahan CPO dialirkan secara bertahap melewati ketiga biosorben tersebut. Dibanding dengan hanya satu jenis biosorben atau dua jenis biosorben, menggunakan tiga jenis biosorben yang berbeda didapatkan peningkatan kualitas air yang tinggi. Peningkatan kualitas pada sistem kontinu ini selain dipengaruhi oleh jenis biosorben juga dipengaruhi oleh massa biosorben yang lebih banyak dimana jika ditotal massanya menjadi 300 gram (Istighfarini, Daud and Edward, 2017).

\subsection{Pengaruh aliran kontinu dan siklus pada sistem.}

Penggunaan sistem kontinu, meski kualitas air yang dihasilkan telah memenuhi persyaratan permen lingkungan hidup tahun 2014 tentang nilai maksimal kandungan air limbah industri yang diperbolehkan dibuang kelingkungan, namun jika dilihat dari warna dan tampilan air secara visual belum melihatkan kualitas yang baik (Mentri Lingkungan Hidup, 2014). Pengolahan secara siklus diharapkan mendapatkan kualitas air yang jauh lebih baik, dan terbukti pada hasil pengujian didapatkan persentase penurunan nilai TSS, BOD dan COD lebih tinggi dibandingkan dengan sistem kontinu. Untuk lebih jelas dapat dilihat Gambar 5. 


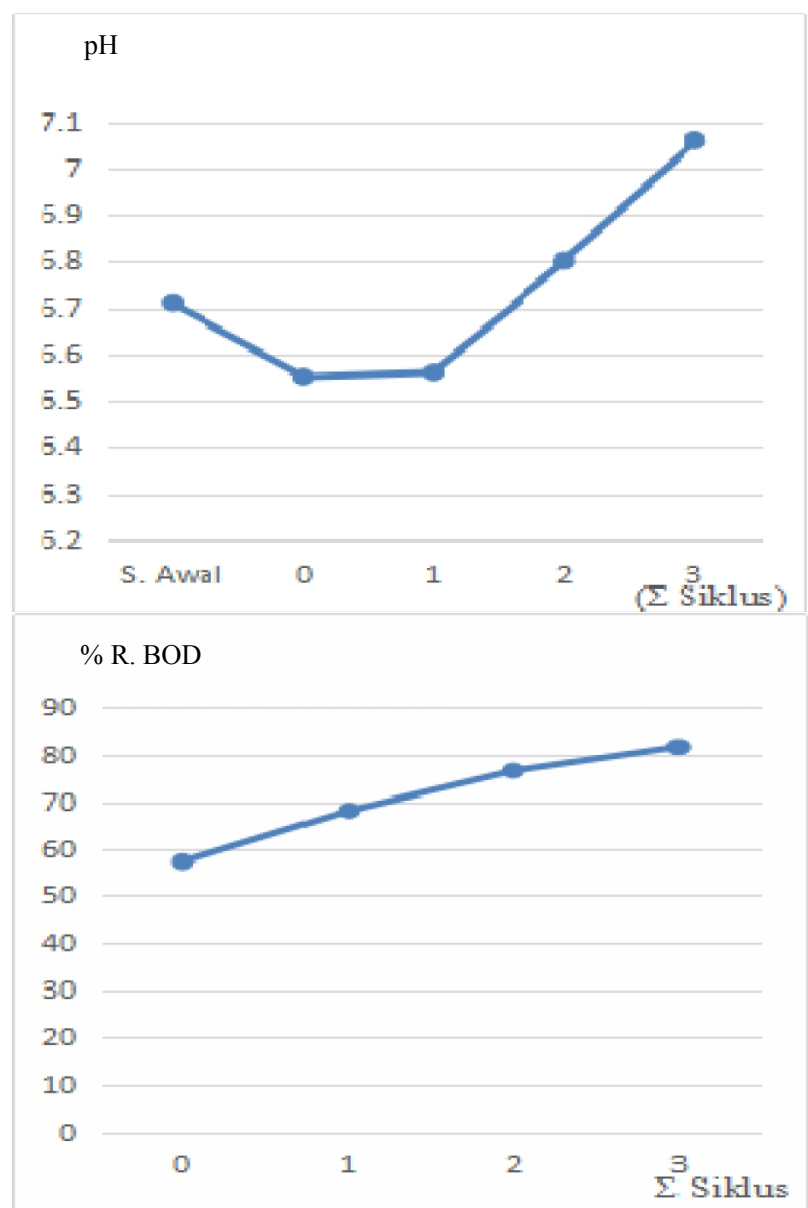

$$
\% \text { R. TSS }
$$

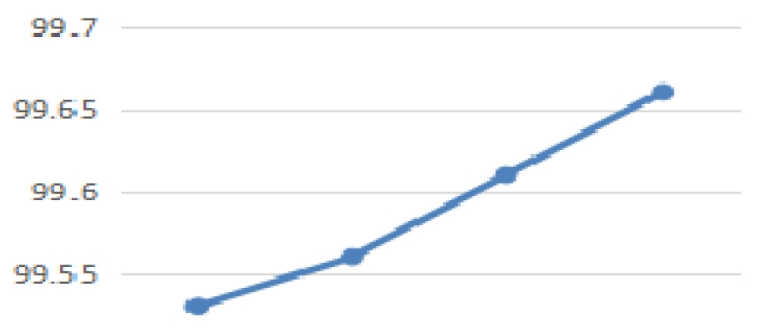

99.5

99.45

$$
10
$$

1

$\%$ R. COD

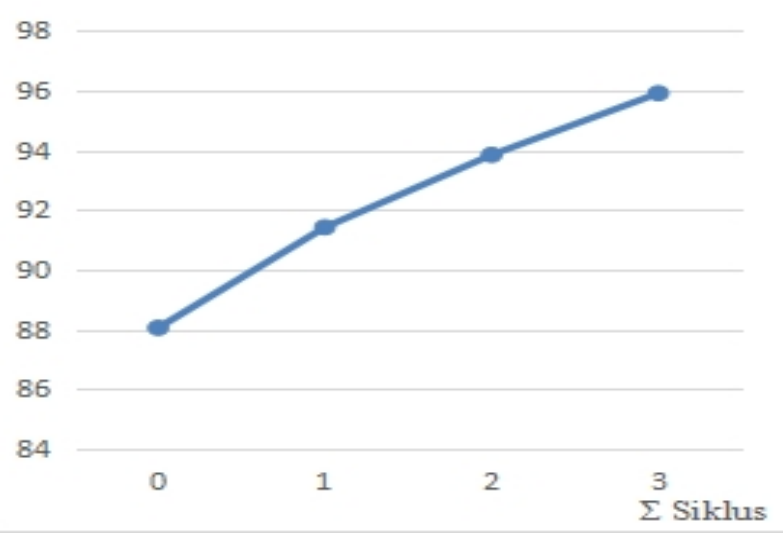

Gambar 5. Effek sistem siklus terhadap pH, penurunan nilai TSS, BOD dan COD air limbah pengolahan CPO.

Dilihat dari data $\mathrm{pH}$ dan penurunan nilai nilai TSS, BOD dan COD dengan sistem siklus menghasilkan kualitas yang lebih baik dari pada sistem tunggal dan sistem kontinu. Perubahan nilai TSS terlihat perubahannya sangat kecil tapi jika dilihat nilai $\mathrm{pH}$, BOD dan COD sangat tinggi. Perubahan nilai TSS kecil ini disebabkan oleh partikel yang sangat halus yang terdapat pada air limbah yang dialirkan tidak terserap pada biosorben karena menggunakan biosorben dengan ukuran besar sehingga jarak antar partikelnya juga besar dan menyebabkan partikel yang sangat halus tidak kontak dengan biosorben atau terlewat sebahagian melewati biosorben (Istighfarini, Daud and Edward, 2017).

Penurunan nilai BOD dan COD semakin tinggi karena pengolahan secara berulang-ulang, ini berarti air melewati biosorben dengan massa yang lebih banyak. Seperti terlihat pada data yang didapatkan dalam mencari massa terbaik dimana semakin banyak massa biosorben yang digunakan semakin bagus pula kualitas air yang dihasilkan (Istighfarini, Daud and Edward, 2017).

\subsection{Menentukan kapasitas biosorpsi biosorben}

Menentukan kapasitas biosorpsi biosorben ditujukan untuk mengetahui kapasitas air limbah yang mampu diolah oleh biosorben. Hasil pengujian untuk menentukan kemampuan filter dalam mengolah air limbah dapat dilihat pada Gambar 6.

Pada gambar 6 terlihat kemampuan biosorben dalam mengolah air limbah, dimana semakin banyak air limbah yang dialirkan atau diolah semakin menurun pula kualitas air limbah, ini menunjukan semakin menurun pulan kinerja biosorben. Penurunan tersebut disebabkan oleh pemakaian secara terus-menerus yang menyebabkan sebagian biosorben sudah mengikat kotoran dari air limbah sehingga kemampuan biosorben jadi berkurang. Kualitas air terjadi penurunan drastis pada pengaliran air limbah 2,5 L ke-VI atau pada volume $15 \mathrm{~L}$, ini menunjukan kemampuan biosorben hampir jenuh dan untuk dapat mengoptimalkan kembali kinerja biosorben maka biosorben harus diregenerasi terlebih dahulu (Istighfarini, Daud and Edward, 2017). 


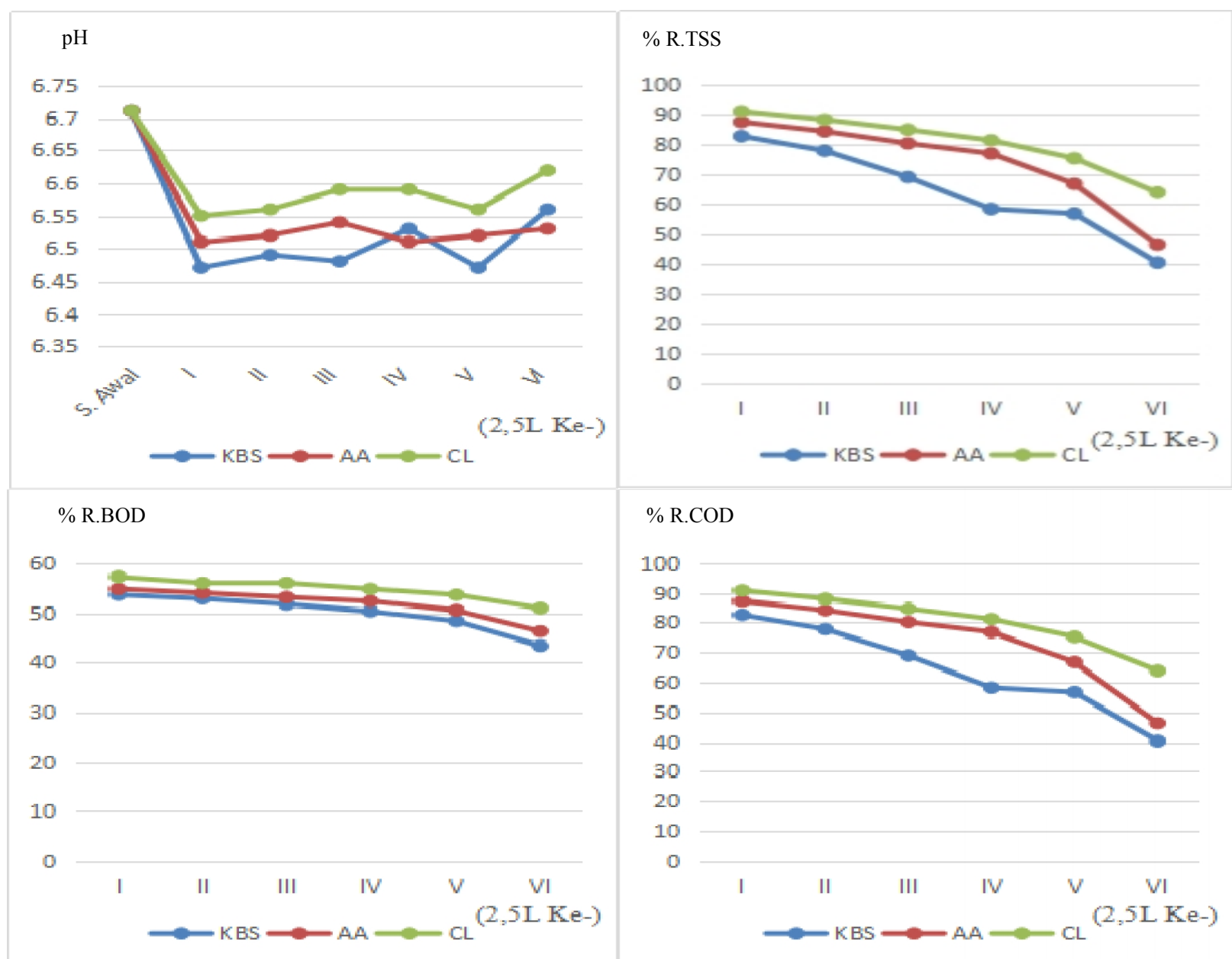

Gambar 6. Uji penentuan kapasitas biosorpsi biosorben terhadap pH, penurunan nilai TSS, BOD dan COD air limbah.

\subsection{Analisis biosorben menggunakan FTIR}

Biosorben kulit batang sagu, arang aktif kulit buah kakao dan cangkang langkitang dianalisis dengan FTIR untuk mengetahui perubahan struktur senyawa yang diamati dari gugus fungsi yang terdapat dalam biosorben. Perubahan gugus fungsi dilihatkan melalui perubahan spektrum yang terbentuk. Hasil analisis FTIR dari ketiga biosorben tersebut dapat dilihat pada Gambar $7-9$.

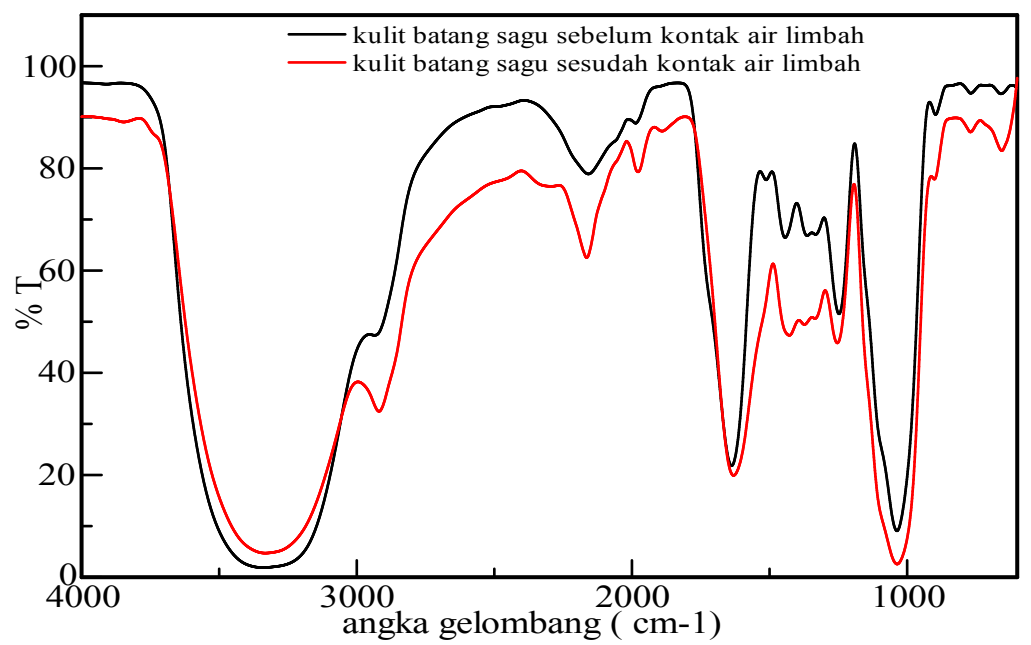

Gambar 7. Spektrum FTIR analisi biosorben kulit batang sagu sebelum dan sesudah kontak dengan air limbah.

Hasil analisis biosorben kulit batang sagu dengan menggunakan FTIR pada Gambar 7. menunjukan ada gugus fungsi yang berbeda antara sebelum dan sesudah kontak dengan air limbah CPO. Perbedaan itu terlihat pada gambar dimana biosorben setelah kontak dengan air limbah CPO terbentuk gugus fungsi baru yaitu gugus $\mathrm{C}$ $\mathrm{H}$ pada angka gelombang $2919,06 \mathrm{~cm}^{-1}$; gugus Al-O pada angka gelombang $1977,89 \mathrm{~cm}^{-1}$ dan gugus $\mathrm{C}-\mathrm{H}$ 
pada angka gelombang $656,67 \mathrm{~cm}^{-1}$. Selain itu juga terjadi perubahan intensitas $(\% \mathrm{~T})$ pada beberapa angka gelombang diantaranaya pada gugus $\mathrm{OH}$ dan $\mathrm{C} \equiv \mathrm{C}$
(Ginting, Syukur and Yulia, 2017; Lestari, Yesicha and Farid, 2019).

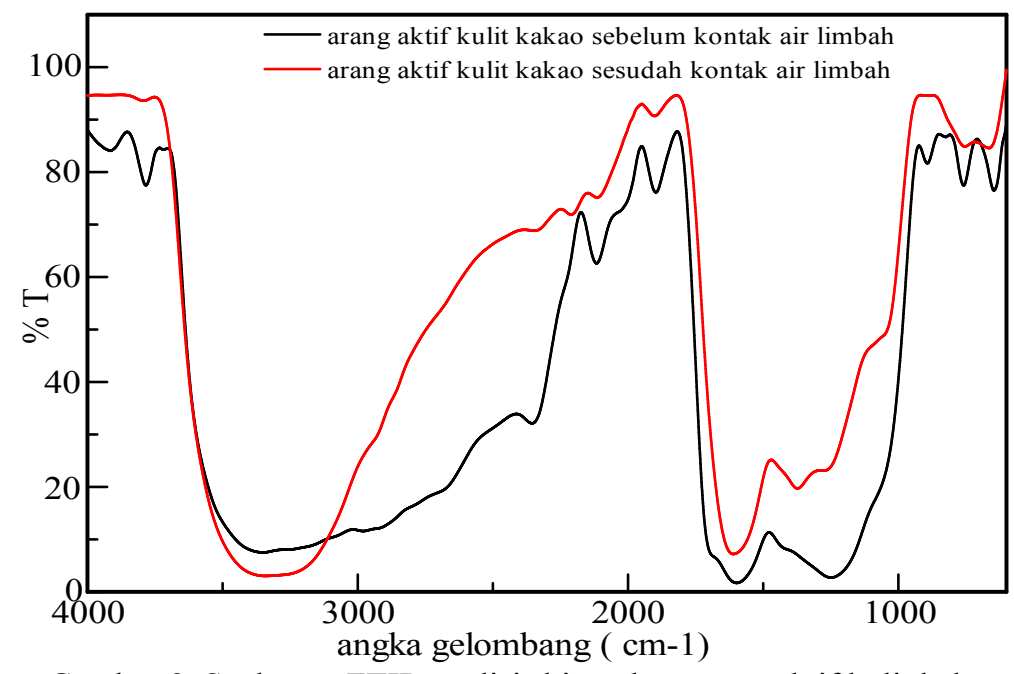

Gambar 8. Spektrum FTIR analisis biosorben arang aktif kulit kakao sebelum dan sesudah kontak dengan air Limbah.

Gambar 8. Memperlihatkan biosorben arang aktif kulit buah kakao terdapat banyak puncak yang hilang setelah biosorben kontak dengan air limbah CPO. Diantaranya adalah gugus $\mathrm{Si}-\mathrm{O}$ pada angka gelombang $2365,01 \mathrm{~cm}^{-1}$, C-H pada angka gelombang 756,36 dan juga terjadi perubahan intensitas $(\% \mathrm{~T})$ pada beberapa area gugus fungsi diantaranya gugus $\mathrm{C}=\mathrm{C}$ dan $\mathrm{O}-\mathrm{H}$ (Ginting, Syukur and Yulia, 2017; Lestari, Yesicha and Farid, 2019).

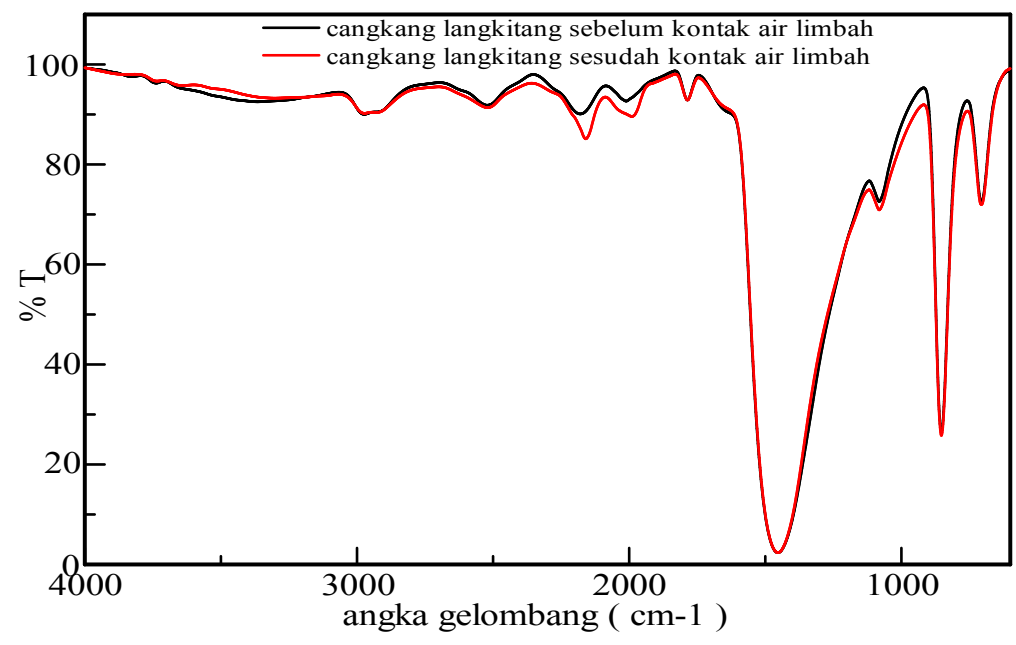

Gambar 9. Spektrum FTIR analisis biosorben cangkang langkitang sebelum dan sesudah kontak dengan airn limbah.

Sama seperti biosorben arang aktif kulit buah kakao, pada Gambar 9. biosorben cangkang langkitang juga terjadi hilangnya sebuah gugus yaitu gugus $\mathrm{O}-\mathrm{H}$ pada angka gelombang $3365,61 \mathrm{~cm}^{-1}$. Selain itu juga terjadi peningkatan intensitas $(\% \mathrm{~T})$ yang berarti meningkatnya konsentrasi suatu senyawa dalam biosorben (Ginting, Syukur and Yulia, 2017; Lestari, Yesicha and Farid, 2019).

Hasil analisis dengan FTIR tersebut dapat disimpulkan bahwa baik biosorben kulit batang sagu, arang aktif kulit buah kakao maupun cangkang langkitang dapat dijadikan sebagai biosorben dalam mengolah air limbah pengolahan CPO karena terbukti ketiga biosorben tersebut dapat mengikat beberapa komponen dalam air limbah (Barus, Zein and Syukri, 2017; Yetri et al., 2017; Fauzia et al., 2018).

\subsection{Analisis biosorben menggunakan SEM}

Analisis menggunakan SEM terhadap biosorben ditujukan untuk melihat bentuk morfologi permukaan biosorben. Bentuk morfologi permukaan yang berbeda antara biosorben sebelum dan sesudah kontak dengan air limbah menunjukan bahwasanya biosorben bekerja dengan baik dalam menyerap komponen-komponen yang terdapat dalam air limbah CPO (Barus, Zein and Syukri, 2017; Yetri et al., 2017; Fauzia et al., 2018). Hasil dari analisis morfologi biosorben dengan menggunakan SEM dapat dilihat pada Gambar 10-12. 


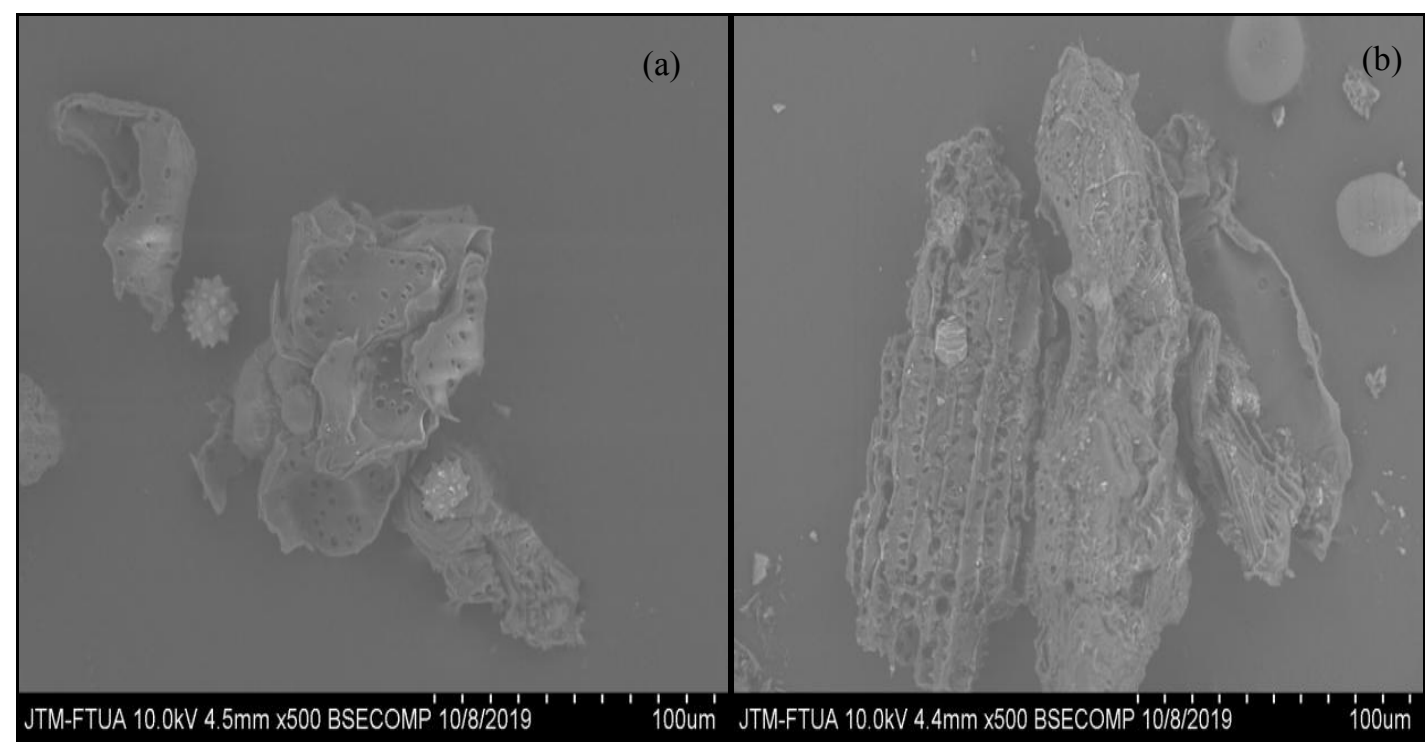

Gambar 10. Hasil analisis morfologi permukaan biosorben kulit batang sagu sebelum (a) dan sesudah kontak dengan airlimbah CPO (b) menggunakan SEM

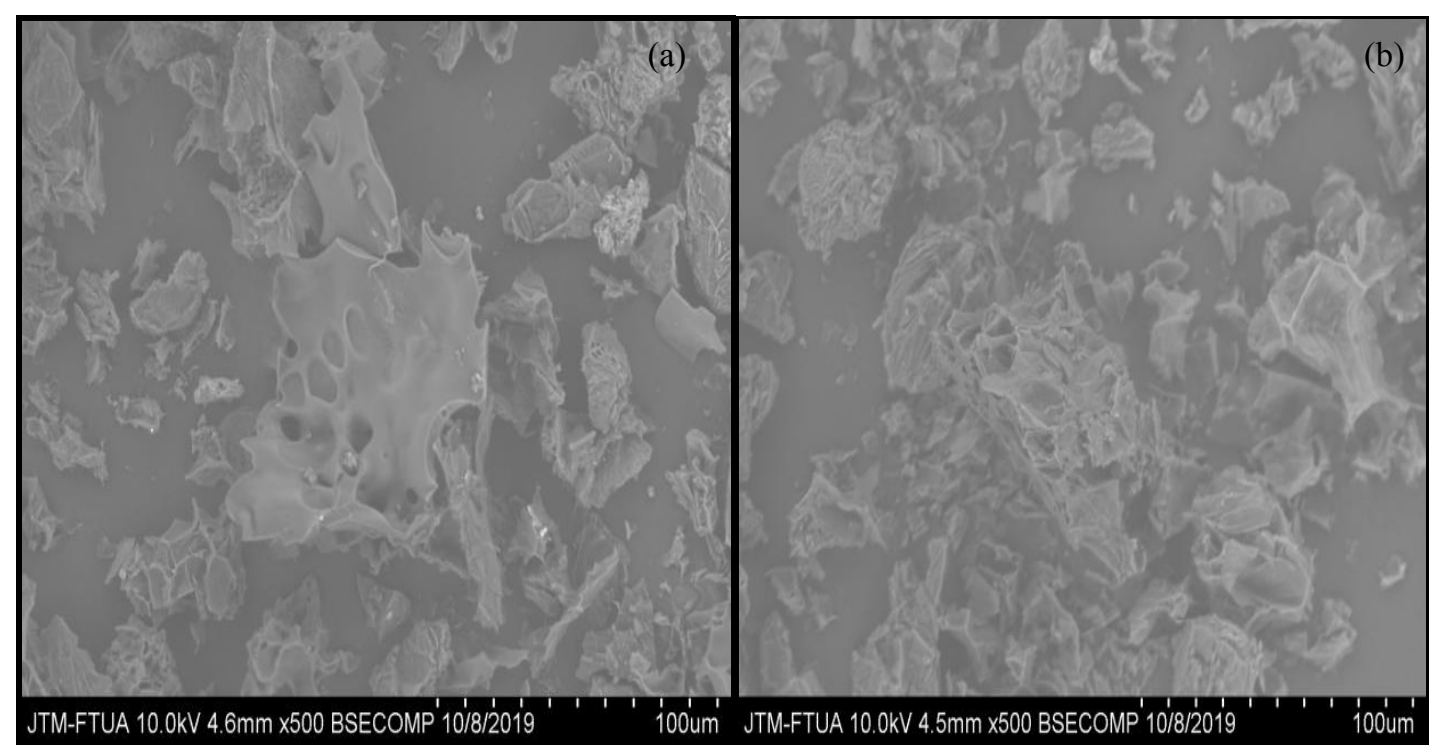

Gambar 11. Hasil analisis morfologi permukaan biosorben arang aktif kulit buah kakao sebelum (a) dan sesudah kontak dengan air limbah CPO (b) menggunakan SEM

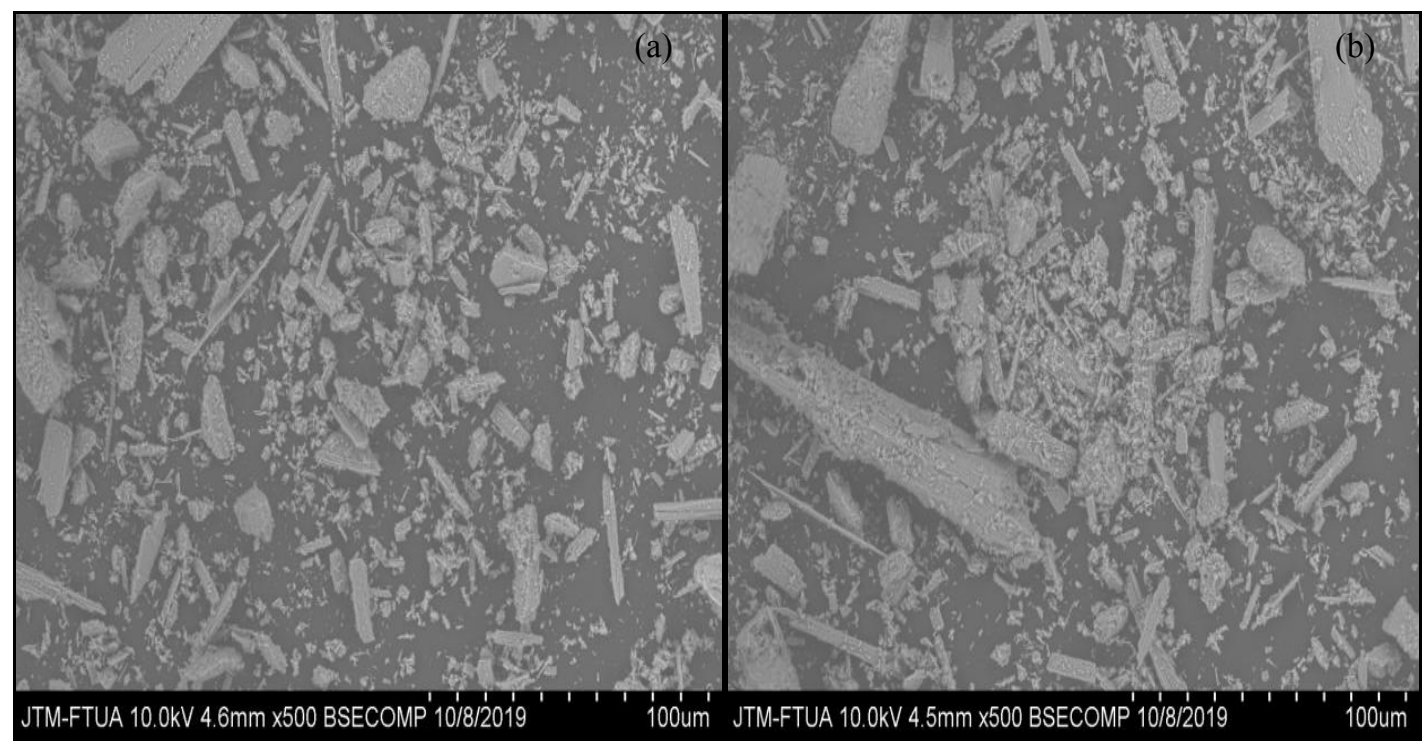

Gambar 12. Hasil analisis morfologi permukaan biosorben cangkang langkitang sebelum (a) dan sesudah kontak dengan air limbah CPO (b) menggunakan SEM. 
Gambar 10 - 12. menjelaskan hasil analisis dengan menggunakan SEM baik biosorben kulit batang sagu, arang aktif kulit buah kakao, maupun cangkang langkitang untuk sebelum kontak dan sesudah kontak dengan air limbah CPO terlihat berbeda. Hasil analisis SEM sebelum kontak dengan air limbah CPO terlihat bentuk morfologi permukaannya masih bagus dan terdapat pori-pori pada permukaannya sedangkan hasil analisis menggunakan SEM terhadap biosorben sesudah kontak dengan air limbah CPO melihatkan bentuk morfologi permukaan yang sudah tidak begitu bagus dan pori-pori sebagian sudah tertutup. Ini menunjukan bahwasanya komponen yang terkandung dalam air limbah berinteraksi dan terserap kedalam pori-pori biosorben (Barus, Zein and Syukri, 2017; Yetri et al., 2017; Fauzia et al., 2018).

\subsection{Analisis komposisi kimia biosorben menggunakan XRF}

Analisis menggunakan XRF dilakukan bertujuan untuk melihat perbedaan komposisi komponen penyusun biosorben antara sebelum dan sesudah kontak dengan air limbah CPO dalam bentuk fraksi persen. Perbedaan tersebut terjadi menandakan ada komponen dari air limbah CPO terdapat atau terikat pada biosorben. Spektrum XRF dan hasil analisis menggunakan XRF untuk ketiga biosorben dapat dilihat pada Tabel 1-3.

Tabel 1.

Perbandingan hasil analisis menggunakan XRF antara komposisi kimia biosorben kulit batang sagu sebelum dan sesudah kontak dengan air limbah:

\begin{tabular}{|c|c|c|c|c|c|c|c|}
\hline \multicolumn{4}{|c|}{ Sebelum kontak dengan air limbah } & \multicolumn{4}{|c|}{ Setelah kontak dengan air limbah } \\
\hline Element & & Oxides & & Element & & Oxides & \\
\hline Compound & Conc $(\%)$ & Compound & Conc $(\%)$ & Compound & Conc $(\%)$ & Compound & Conc $(\%)$ \\
\hline $\mathrm{Si}$ & $9,06 \%$ & $\mathrm{SiO}_{2}$ & $10,88 \%$ & $\mathrm{Si}$ & $36,06 \%$ & $\mathrm{SiO}_{2}$ & $47,65 \%$ \\
\hline $\mathrm{Ca}$ & $15,87 \%$ & $\mathrm{CaO}$ & $8,26 \%$ & $\mathrm{Ca}$ & $33,90 \%$ & $\mathrm{CaO}$ & $22,52 \%$ \\
\hline $\mathrm{Fe}$ & $2,13 \%$ & $\mathrm{Fe}_{2} \mathrm{O}_{3}$ & $1,03 \%$ & $\mathrm{Fe}$ & $5,385 \%$ & $\mathrm{Fe}_{2} \mathrm{O}_{3}$ & $3,17 \%$ \\
\hline $\mathrm{K}$ & - & $\mathrm{K}_{2} \mathrm{O}$ & - & $\mathrm{K}$ & $0,89 \%$ & $\mathrm{~K}_{2} \mathrm{O}$ & $0,54 \%$ \\
\hline $\mathrm{Ni}$ & - & $\mathrm{NiO}$ & - & $\mathrm{Ni}$ & $0,13 \%$ & $\mathrm{NiO}$ & $0,06 \%$ \\
\hline $\mathrm{Cu}$ & - & $\mathrm{CuO}$ & - & $\mathrm{Cu}$ & $0,07 \%$ & $\mathrm{CuO}$ & $0,03 \%$ \\
\hline $\mathrm{Zn}$ & - & $\mathrm{ZnO}$ & - & $\mathrm{Zn}$ & $0,30 \%$ & $\mathrm{ZnO}$ & $0,15 \%$ \\
\hline $\mathrm{Ba}$ & - & $\mathrm{BaO}$ & - & $\mathrm{Ba}$ & $0,09 \%$ & $\mathrm{BaO}$ & $0,03 \%$ \\
\hline
\end{tabular}

Hasil analisis dengan menggunakan XRF dapat menentukan komposisi unsur dan unsur-unsur oksida logam. Hasil analisis dengan XRF untuk biosorben kulit batang sagu sebelum dan sesudah kontak dengan air limbah CPO dapat dilihat pada Tabel 1. Pada hasil analisis dengan XRF, biosorben sebelum dan sesudah kontak dengan air limbah CPO didapatkan hasil yang berbeda, dimana sesudah kontak dengan air limbah CPO kandungan unsur $\mathrm{Si}$, $\mathrm{Ca}$ dan Fe beserta oksida logamnya mengalami peningkatan. Unsur dan oksida logamnya yang kandungannya mengalami peningkatan drastis adalah unsur $\mathrm{Si}, \mathrm{Ca}, \mathrm{SiO}_{2}$ dan $\mathrm{CaO}$, ini menandakan di dalam air limbah CPO banyak mengandung unsur Si dan Ca. pada tabel beberapa unsur hanya terbaca pada biosorben kulit batang sagu yang sudah kontak dengan air limbah, ini menandakan biosorben mengikat unsur logam yang berasal dari air limbah tersbut (Ginting, Syukur and Yulia, 2017; Lestari, Yesicha and Farid, 2019).

Tabel 2.

Perbandingan hasil analisis menggunakan XRF antara komposisi kimia biosorben arang aktif kulit buah kakao sebelum dan sesudah kontak dengan air limbah:

\begin{tabular}{|c|c|c|c|c|c|c|c|}
\hline \multicolumn{4}{|c|}{ Sebelum kontak dengan air limbah } & \multicolumn{4}{|c|}{ Setelah kontak dengan air limbah } \\
\hline Element & & Oxides & & Element & & Oxides & \\
\hline Compound & Conc $(\%)$ & Compound & Conc $(\%)$ & Compound & Conc $(\%)$ & Compound & Conc $(\%)$ \\
\hline $\mathrm{Mg}$ & $0 \%$ & $\mathrm{MgO}$ & $0 \%$ & $\mathrm{Mg}$ & $4,22 \%$ & $\mathrm{MgO}$ & $5,21 \%$ \\
\hline $\mathrm{Si}$ & $21,315 \%$ & $\mathrm{SiO}_{2}$ & $28,33 \%$ & $\mathrm{Si}$ & $23,70 \%$ & $\mathrm{SiO}_{2}$ & $34,55 \%$ \\
\hline $\mathrm{Ca}$ & $27,85 \%$ & $\mathrm{CaO}$ & $17,62 \%$ & $\mathrm{Ca}$ & $51,78 \%$ & $\mathrm{CaO}$ & $38,43 \%$ \\
\hline $\mathrm{Zn}$ & $0,21 \%$ & $\mathrm{ZnO}$ & $0,10 \%$ & $\mathrm{Zn}$ & $0,41 \%$ & $\mathrm{ZnO}$ & $0,23 \%$ \\
\hline
\end{tabular}

Hasil analisis dengan XRF untuk biosorben arang aktif kulit buah kakao sebelum dan sesudah kontak dengan air limbah CPO didapatkan hasil yang berbeda. Pada data XRF unsur $\mathrm{Mg}, \mathrm{Si}, \mathrm{Ca}$ dan $\mathrm{Zn}$ beserta oksidanya mengalami peningkatan konsentrasi, ini berarti biosorben arang aktif kulit kakao dapat mengikat unsur tersebut dari air limbah. Konsentrasi unsur dan oksidanya yang mengalami peningkatan paling besar adalah unsur $\mathrm{Ca}$, ini menandakan biosorben efektif menarik unsur Ca sama halnya dengan biosorben kulit batang sagu. Perbedaan antara biosorben kulit batang sagu dan arang aktif kulit buah kakao terletak pada kemampuan mengikat unsur $\mathrm{Mg}, \mathrm{Si}, \mathrm{Zn}, \mathrm{K}, \mathrm{Ni}, \mathrm{Cu}, \mathrm{Zn}$, dan $\mathrm{Ba}$, dimana biosorben kulit batang sagu lebih efektif mengikat unsur $\mathrm{Si}, \mathrm{Zn}, \mathrm{K}, \mathrm{Ni}, \mathrm{Cu}, \mathrm{Zn}$, dan $\mathrm{Ba}$ sedangkan biosorben arang aktif kulit buah kakao lebih efektif dalam mengikat unsur Mg dan Zn (Ginting, Syukur and Yulia, 2017; Lestari, Yesicha and Farid, 2019). 
Tabel 3.

Perbandingan hasil analisis menggunakan XRF antara komposisi kimia biosorben cangkang langkitang sebelum dan sesudah kontak dengan air limbah:

\begin{tabular}{|c|c|c|c|c|c|c|c|}
\hline \multicolumn{4}{|c|}{ Sebelum kontak dengan air limbah } & \multicolumn{4}{|c|}{ Setelah kontak dengan air limbah } \\
\hline Element & & Oxides & & Element & & Oxides & \\
\hline Compound & Conc $(\%)$ & Compound & Conc $(\%)$ & Compound & Conc $(\%)$ & Compound & Conc $(\%)$ \\
\hline $\mathrm{Al}$ & $0,29 \%$ & $\mathrm{Al}_{2} \mathrm{O}_{3}$ & $0,48 \%$ & $\mathrm{Al}$ & $0,33 \%$ & $\mathrm{Al}_{2} \mathrm{O}_{3}$ & $0,53 \%$ \\
\hline $\mathrm{P}$ & $0,36 \%$ & $\mathrm{P}_{2} \mathrm{O}_{5}$ & $0,68 \%$ & $\mathrm{P}$ & $0,35 \%$ & $\mathrm{P}_{2} \mathrm{O}_{5}$ & $0,69 \%$ \\
\hline $\mathrm{Ca}$ & $96,97 \%$ & $\mathrm{CaO}$ & $96,81 \%$ & $\mathrm{Ca}$ & $96,85 \%$ & $\mathrm{CaO}$ & $96,65 \%$ \\
\hline $\mathrm{Ti}$ & $0 \%$ & $\mathrm{TiO}_{2}$ & $0 \%$ & $\mathrm{Ti}$ & $0,01 \%$ & $\mathrm{TiO}_{2}$ & $0,01 \%$ \\
\hline $\mathrm{Cr}$ & $0,035 \%$ & $\mathrm{Cr}_{2} \mathrm{O}_{3}$ & $0,03 \%$ & $\mathrm{Cr}$ & $0,02 \%$ & $\mathrm{Cr}_{2} \mathrm{O}_{3}$ & $0,02 \%$ \\
\hline $\mathrm{Mn}$ & $0,10 \%$ & $\mathrm{MnO}$ & $0,09 \%$ & $\mathrm{Mn}$ & $0,09 \%$ & $\mathrm{MnO}$ & $0,08 \%$ \\
\hline $\mathrm{Fe}$ & $0,69 \%$ & $\mathrm{Fe}_{2} \mathrm{O}_{3}$ & $0,65 \%$ & $\mathrm{Fe}$ & $0,88 \%$ & $\mathrm{Fe}_{2} \mathrm{O}_{3}$ & $0,83 \%$ \\
\hline
\end{tabular}

Sama dengan biosorben arang aktif, analisis menggunakan XRF untuk biosorben cangkang langkitang sebelum dan sesudah kontak dengan air limbah pengolahan CPO juga didapatkan hasil yang berbeda. Pada biosorben cangkang langkitang unsur utamanya adalah $\mathrm{Ca}$ dimana kandungannya mencapai 96,97\%. Kandungan Ca yang besar inilah yang dapat meningkatkan $\mathrm{pH}$ dari air limbah CPO. Karena kandungan $\mathrm{Ca}$ sedangkan dalam air limbah juga mengandung unsur $\mathrm{Ca}$ yang besar ( berdasarkan data XRF biosorben kulit batang sagu dan arang aktif kulit buah kakao), ini menyebabkan pengaruh biosorben dalam mengikat unsur lain terlihat kecil (Ginting, Syukur and Yulia, 2017; Lestari, Yesicha and Farid, 2019).

Hasil analisis ketiga biosorben, baik biosorben kulit batang sagu, arang aktif kulit buah kakao maupun cangkang langkitang dengan menggunakan XRF dapat disimpulkan bahwa dalam air limbah CPO terdapat beberapa unsur atau senyawa atau oksida logam didalamnya. Terjadinya perubahan persentase komposisi unsur atau oksida logam tertentu pada analisis menggunakan XRF untuk bisosorben setelah kontak dengan air limbah CPO berarti antara biosorben dengan air limbah CPO terjadi penyerapan atau interaksi.

\section{Kesimpulan}

Penelitian pengolahan air limbah pengolahan CPO dengan menggunakan biosorben kulit sagu, arang aktif kulit kakao dan cangkang langkitang dapat disimpulkan bahwa ketiga biosorben tersebut secara bersamaan dapat digunakan dalam mengolah air limbah CPO. Dalam penelitian pada massa 100 gram dan laju alir air keluar $100 \mathrm{~mL} /$ menit dengan sistem kontinu dan tiga kali siklus ketiga biosorben mampu memperbaiki kualitas air limbah pengolahan CPO. Penggunaan ketiga biosrben tersebut sangat efektif dalam menetralkan $\mathrm{pH}$ dan menurunkan nilai TSS, BOD dan COD dari air limbah tersebut. Penggunaan masing-masing biosorben dengan massa 100 gram mapu mengolah air limbah sebanyak 12,5L, Aplikasi ke industri pengolahan CPO dapat dilakukan dengan penggunaan biosorben dengan massa yang jauh lebih besar.

Analisis biosorben menggunakan FTIR, SEM dan XRF diperoleh hasil yang berbeda antara biosorben sebelum dan sesudah kontak dengan air limbah CPO. Perbedaan hasil yang ditunjukan menandakan komponen dalam air limbah CPO terjadi interaksi atau terserap kedalam biosorben sehingga penggunaan ketiga biosorben ini dapat direkomendasikan dalam pengolahan air limbah pada industri pengolahan CPO dengan melalui beberapa tahap penelitian terlebih dahulu.

\section{Saran}

Penelitian berikutnya disarankan agar peneliti lainnya dapat melakukan penelitian dengan variasi massa, laju alir yang lebih tinggi sehingga dapat diaplikasikan untuk rumah tangga dan industri serta bernilai komersil atau peneliti lainnya dapat melakukan penelitian dengan variabel yang sama untuk pengolahan air limbah industri yang berbeda.

\section{Ucapan terima kasih}

Penulis mengucapkan terimakasih kepada industri pengolahan CPO, PT. Wilmar Nabati Indonesia, Teluk Bayur, Kota Padang, Sumatera Barat beserta seluruh pihak yang terlibat dalam proses penulisan dan penyusunan artikel ini.

\section{Daftar pustaka}

Barus, N. D., Zein, R. and Syukri, 2017. Penjernihan air sumur menjadi air layak pakai dengan memanfaatkan karang dan cangkang langkitang (faunus ater) menggunakan kolom. scholar unand, hal. 2-4. Tersedia pada: http://scholar.unand.ac.id/26795/.

Cheah, W. Y. et al., 2018. Microalgae cultivation in palm oil mill effluent (POME) for lipid production and pollutants removal. Energy Conversion and Management. Elsevier, 174(June), hal. 430-438. doi: 10.1016/j.enconman.2018.08.057.

Dharma, U. S. and Prasetyo, G., 2012. Pengaruh perubahan laju aliran terhadap tekanan dan jenis aliran yang terjadi pada alat uji praktiikum mekanika fluida. Turbo: Jurnal Program Studi Teknik Mesin, 1(2). doi: $10.24127 /$ trb.v1i2.653.

Fauzia, S. et al., 2018. Study of equilibrium, kinetic and thermodynamic for removal of $\mathrm{Pb}$ (II) in aqueous solution using Sago bark (Metroxylon sago). AIP Conference Proceedings, 2023, hal. 1-8. doi: 10.1063/1.5064078.

Ginting, S. B., Syukur, S. D. and Yulia, Y., 2017. Kombinasi adsorben biji kelor - zeolit alam lampung untuk meningkatkan efektivitas penyerapan logam $\mathrm{Pb}$ dalam air secara kontinu pada kolom fixed bed adsorber. Jurnal Rekayasa Proses, 11(1), hal. 1. doi: 
10.22146/jrekpros. 23154 .

Iqbal, A. et al,. 2018. Pseudomonas aeruginosa USM$\mathrm{AR} 2 / \mathrm{SiO} 2$ biosorbent for the adsorption of methylene blue. Journal of Environmental Chemical Engineering. Elsevier, 6(4), hal. 4908-4916. doi: 10.1016/j.jece.2018.07.025.

Istighfarini, S. A. E., Daud, S. and Edward, H., 2017. Pengaruh massa dan ukuran partikel adsorben sabut kelapa terhadap efisiensi penyisihan Fe pada air gambut. Jom FTEKNIK, 4(1), hal. 1-8.

Lestari, I., Yesicha, N. T. and Farid, F., 2019. Amobilisasi biji durian (durio zibethinus) dalam Caalginat sebagai biosorben zat warna metilen biru. Chempublish Journal, 4(1), hal. 19-29. doi: 10.22437/chp.v4i1.6900.

Menteri Lingkungan Hidup, 2014. KepMen LH nomor 5 / 2014. Peraturan Menteri Lingkungan Hidup, (345), hal. 1-85. Tersedia pada: ditjenpp.kemenkumham.go.id/arsip/bn/2014/bn18152014.pdf.

Mohd-Nor, D. et al., 2018. Alcaligenaceae and Chromatiaceae as reliable bioindicators present in palm oil mill effluent final discharge treated by different biotreatment processes. Ecological Indicators, 95(May), hal. 468-473. doi: 10.1016/j.ecolind.2018.08.007.

Pratiwi, I., Zein, R. and Aziz, H., 2016. Intisari pemanfaatan cangkang langkitang (Faunus ater) Sebagai Biosorben Ion Logam Cd(II) dan Cr(VI). scholar.unand.ac.id, (Ii), hal. 0-1. Tersedia pada: http://scholar.unand.ac.id/16612/.

Purnamawati, H. and Utami, B., 2014. Pemanfaatan limbah kulit buah kakao (theobroma cocoa L) sebagai adsorben zat warna rhodamin B. Prosiding Seminar Nasional Fisika dan Pendidikan Fisika (SNFPF), 5(1), hal. 12.

Rodrigues, T. O. et al., 2014. GHG balance of crude palm oil for biodiesel production in the northern region of Brazil. Renewable Energy. Elsevier Ltd, 62(1), hal. 516-521. doi: 10.1016/j.renene.2013.08.006.

Safa, Y. and Bhatti, H. N., 2011. Biosorption of direct red-31 and direct orange-26 dyes by rice husk: application of factorial design analysis. Chemical Engineering Research and Design. Institution of Chemical Engineers, 89(12), hal. 2566-2574. doi: 10.1016/j.cherd.2011.06.003.

Sy, S. et al., 2017. Pengaruh laju alir inlet reaktor MSL terhadap reduksi BOD, COD, TSS, dan minyak/lemak limbah cair industri minyak goreng. Jurnal Litbang Industri, 7(1), hal. 41. doi: 10.24960/jli.v7i1.2768.41-51.
Tabaraki, R. and Heidarizadi, E., 2018. Simultaneous biosorption of Arsenic (III) and Arsenic (V): Application of multiple response optimizations. Ecotoxicology and Environmental Safety. Elsevier Inc., 166(September), hal. 35-41. doi: 10.1016/j.ecoenv.2018.09.063.

Theerachat, M., Tanapong, P. and Chulalaksananukul, W., 2017. The culture or co-culture of Candida rugosa and Yarrowia lipolytica strain rM-4A, or incubation with their crude extracellular lipase and laccase preparations, for the biodegradation of palm oil mill wastewater. International Biodeterioration and Biodegradation. Elsevier Ltd, 121(1), hal. 11-18. doi: 10.1016/j.ibiod.2017.03.002.

Wahi, R. et al., 2014. Esterification of M. sagu bark as an adsorbent for removal of emulsified oil. Journal of Environmental Chemical Engineering. Elsevier B.V., 2(1), hal. 324-331. doi: 10.1016/j.jece.2013.12.010.

Wong, Y. S. et al., 2013. Methane gas production from palm oil wastewater-an anaerobic methanogenic degradation process in continuous stirrer suspended closed anaerobic reactor. Journal of the Taiwan Institute of Chemical Engineers. Taiwan Institute of Chemical Engineers, 45(3), hal. 896-900. doi: 10.1016/j.jtice.2013.10.002.

Yani, M., Nurcahyani, P. R. and Rahayunigsih, M., 2014. Penghilangan bau amonia menggunakan teknik biofilter dengan bahan pengisi koral dan arang aktif yang diinokulasi dengan bakteri pengoksidasi amonia. J Tek Ind Pert, 23(1), hal. 22-29.

Yetri, Y. et al,. 2017. Theobroma cacao peels activated carbon as potential adsorben for tartrazine. Politeknik Negeri Padang.

Zahrim, A. Y. et al., 2017. Effective coagulationflocculation treatment of highly polluted palm oil mill biogas plant wastewater using dual coagulants: Decolourisation, kinetics and phytotoxicity studies. Journal of Water Process Engineering. Elsevier Ltd, 16(1), hal. 258-269. doi: 10.1016/j.jwpe.2017.02.005.

Zein, R., Swesti, N., et al., 2016. Peat water treatment by using multi soil layering ( MSL ) method. Der Pharma Chemica, 8(12), hal. 254-261.

Zein, R., Ningsih, S., et al., 2016. Biological and chemical sciences treatment of waste water noodle industry with a multi-soil-layering ( MSL ). Research Journal of Pharmaceutical, Biological and Chemical Sciences, 7(88), hal. 88-94.

Zein, R. et al., 2018. Kulit salak sebagai biosorben potensial untuk pengolahan timbal(II) dan cadmium(II) dalam larutan. Chimica et Natura Acta, 6(2), hal. 56. doi: 10.24198/cna.v6.n2.17857. 